Vol. 4, No. 1 pp. 17-26.

2021

DOI: $10.53935 / 2641-533 x . v 4 i 1.62$

(C) 2021 by the authors; licensee Academic Publishing Group

\title{
Analyzing Descriptive Writing among Chinese Undergraduates According to Gender
}

Qian CHEN: PhD Student, Faculty of Education and Liberal Studies, City University Malaysia, Petaling Jaya, Selangor, Malaysia.

-Subadrah Madhawa Nair: Faculty of Education and Liberal Studies, City University Malaysia, Petaling Jaya, Selangor, Malaysia.

\begin{abstract}
The aim of the study is to assess the Chinese undergraduate students' EFL descriptive writing ability according to gender and to explore four EFL lecturers' views on how to help students enhance their EFL descriptive writing. This study employed descriptive research design using the QUAN-qual model. A descriptive writing test was used as an instrument and the essays of the students were marked by a lecturer. Purposive sampling was used to select samples which consists of 400 Chinese undergraduate students (200 males and 200 females) from Hunan City University in Hunan Province, China. Before the actual study, the researcher carried out a pilot test to investigate the reliability and validity of the instrument (descriptive writing test). The results obtained from the quantitative data showed that female students outperformed male students in their overall writing as well as each component of the writing. In relation to students' writing level, the lecturers emphasized that it is very crucial to utilize the Process Approach in class to enhance students' vocabulary and grammar foundation. In addition, students are required to practice writing more frequently which can arouse their enthusiasm in learning English.
\end{abstract}

Key words: Descriptive writing, Gender, Chinese undergraduates, EFL, Gender, Process approach.

JEL Classification: 120 Education and Research Institutions: General, 121 Analysis of Education, 126 Returns to Education, 129 Education: Other

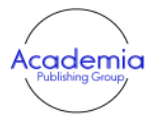

International Journal of Educational Studies

Volume 4, Issue 1, pp. 17-26

2021

DOI: 10.53935/2641-533x.v4i1.62

Corresponding Author: Subadrah Madhawa

Email:subadrah.nair@city.edu.my

Funding: This study received no specific

financial support.

Article History:

Received: 3 September 2021

Revised: 29 September 2021

Accepted: 18 October 2021

Published: 1 November 202

(C) 2021 by the authors; licensee Academic Publishing Group

\section{Introduction}

\subsection{Background of the Study}

In the age of globalization, EFL writing skills are very important in the areas of education, communication as well as business cooperation. As such, colleges and universities still regard the cultivation of students' writing ability as one of the most important teaching objectives. However, many researches showed that it is very difficult for a person to achieve high level of writing ability (Ronald \& Bascom, 2007). Graham and Harris (2005) indicated that writing is very difficult and makes students frustrated. Study by Cargill and Kalikoff (2007) also showed that the process of producing, organizing, and putting ideas into the written text is the most difficult part in writing. In addition, Divsar and Heydari (2017) pointed out that comparing with writing in the first language, writing in a foreign language is definitely more difficult. Moreover, Cumming (2003) revealed in his study that comparing to other parts of writing, it is found by the foreign language learners that vocabulary and grammar are the most difficult parts in writing.

Nowadays, English writing has been a critical issue in college English in China. According to Liu (2015) writing is an output of learning and it requires a high level of comprehensive language ability. Therefore, 


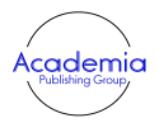

International Journal of Educational
Studies
Volume 4, Issue 1, pp. $17-26$
2021
DOI: $10.53935 / 2641-533 x . v 4 i 1.62$
a Corresponding Author: Subadrah Madhawa
Nair
Email: subadrah.nair@ @ity.edu.my
Funding: This study received no specific
financial support.
Article History:
Received: 3 September 2021
Revised: 29 September 2021
Accepted: 18 October 2021
Published: 1 November 2021
○ 2021 by the authors; licensee Academic
Publishing Group
Studies

Volume 4, Issue 1, pp. 17-26

DOI: $10.53935 / 2641-533 x . v 4 i 1.62$

Received: 3 September 2021

Published: 1 November 202

Publishing Group lacking of proficiency in English language will surely affect the quality of writing (Cole, 2015). The essays written by EFL students usually contain many kinds of errors. In other words, for English learners, English writing is always considered to be a great challenge. It is often reported that college students' English language ability, particularly their writing proficiency, is declining in China (Liu, 2015). Although students are supposed to obtain a good performance in writing, it is found that a large number of Chinese undergraduates do not have good writing skills when they enter the workforce.

Therefore, these problems have aroused the concern of many scholars and researchers. Ibrahim (2015) indicated that some study attributed the problems in students' writing to teachers' teaching and the awareness of educational administrations and some may impute them to institutional constraints on students' ability to improve writing. However, several studies investigated the effect of gender on writing skills. Some researchers such as Chavez (2001); Latham (2002) and Oxford (1994) revealed that gender is a very important issue in their research.

Gender differences have been the subject of many studies over the years, which have shown that gender is an influential variable in almost all social phenomena, including language (Voyer \& Voyer, 2014). As such, gender can be a considerable source of differences among language learners. Therefore, teachers must consider the influence of gender on language learning in the teaching process (Corona et al., 2017).

There are only a few studies on gender differences in Chinese EFL learners' writing ( $\mathrm{Li}$, Chen, \& Banerjee, 2020). This study takes college English learners from Hunan City University as the research sample. Based on the writing rubric provided by the researcher, the study analyzes and compares each part of the students' writings according to gender. In this study, the focus is mainly to explore whether there is a significant difference in undergraduates' writing skills according to gender. In addition, the overall performance as well as each component of the writings were analyzed according to gender using Independent samples t-test. This study also investigated the lecturers' perceptions on how to enhance their students' writing proficiency.

\subsection{Research Questions}

1. Is there a significant difference in the overall mean score for descriptive writing among Chinese undergraduates according to gender?

2. Is there a significant difference in the mean score for introduction of descriptive writing among Chinese undergraduates according to gender?

3. Is there a significant difference in the mean score for focus on topic of descriptive writing among Chinese undergraduates according to gender?

4. Is there a significant difference in the mean score for supporting details of descriptive writing among Chinese undergraduates according to gender?

5. Is there a significant difference in the mean score for adding personal opinion of descriptive writing among Chinese undergraduates according to gender?

6. Is there a significant difference in the mean score for sentence structure of descriptive writing among Chinese undergraduates according to gender?

7. Is there a significant difference in the mean score for coherence and cohesion of descriptive writing among Chinese undergraduates according to gender?

8. Is there a significant difference in the mean score for conclusion of descriptive writing among Chinese undergraduates according to gender?

9. Is there a significant difference in the mean score for grammar and mechanics of descriptive writing among Chinese undergraduates according to gender?

10. What are the EFL lecturers' perceptions on how to improve students' writing skills?

\section{Review of Literature}

There are many deficiencies and problems with the writing skills of Chinese undergraduates (Sang, 2017). Therefore, the teaching of college English writing needs an effective system. For the purpose of improving writing skills, the process-based writing approach has always been given great importance. Process Approach plays an important role in teaching writing. 


\subsection{Product Approach and Process Approach in Teaching Writing}

Product approach is a traditional teaching method. According to Tangpermpoon (2008) teaching writing in this way can help students strengthen the grammar and syntactic forms of writing in the second or foreign language. Therefore, this method mainly teaches students how to use vocabulary, syntax and cohesive device (Badger \& White, 2000). This traditional teaching method encourages students to analyse imitate model texts (Hasan \& Akhand, 2010).

In the study of Badger and White (2000) there are four stages in the product approach in teaching writing: familiarity, controlled writing, guided writing and free writing. First of all, the teacher guides the students to familiarize with the features of a particular text. Then, through giving the students some grammar exercises, the teacher controls their learning activities and related vocabulary. After that, students are instructed to write according to the template. The last stage is for students to write another similar text freely.

According to Akyol, Çakıroğlu, and Kuruyer (2014); Tompkins (2002) and Tavsanli and Kaldırım (2020) in stead of merely considering writing as creating a text, the process-based approach elaborates it as a process. The writing process is divided into certain steps based on the process approach principle, which provides students with useful writing skills. The process-based writing approach consist of five stages: pre-writing preparation, drafting, writing through reviewing and organizing, editing, and sharing or publishing.

In addition, Zhang (2021) stated that it is proper to regard writing as several steps for writers to create a specific discourse from a particular situation. In the students' writing process, teachers provide the necessary language knowledge and writing skills to guide and facilitate their writings.

According to Andrade (2005) assessment could take a closer look at students' writing. As such, teachers must understand what really value in good writings and they should develop specific and well-defined criteria for both the teachers and students to see. In other words, teachers must make students know what they need to know and what they need to do in their teaching process.

From the process of scoring, it is known that the rubrics assessment is very useful because it made the writing instruction effective. Rubrics made the teachers' instruction effective as they were able to make their expectation clear and guide students how to meet those expectations. Through using rubrics, teachers are able to focus their instruction on students' specific needs and monitor students' progress. Most importantly, rubrics paved the way for teachers to use the writing process approach that values the process rather than the product in students' writing.

\subsection{Studies on Gender Differences in Second Language Acquisition}

Freud (1974) pointed out that anatomy does not determine a person's fate, but that a learner's gender can have a profound effect on how they learn language, and those patterns in turn affect proficiency. According to Bevilacqua (2017) the brain functions are quite different between males and females, and the study also indicated that language function is more organized in females. Moreover, many studies have shown that females and males do perform and behave differently in second language acquisition (Hamdi \& Dabaghi, 2012).

Oxford (2015) indicated that it is necessary to understand the relationship between language learning and gender differences. She worked on gender differences in language classrooms, and her research focuses on females' learning styles and the specific learning strategies that males often utilize. Moreover, Chavez (2001) indicated that as males and females obtain different ability in learning a foreign language and they adopt different learning strategy, the EFL teachers can aim to provide the best possible guidance to both male and female students by adjusting teaching practices.

It has been observed that female's language progress is more rapid than that of males (Montenegro \&

International Journal of Educational Studies

Volume 4, Issue 1, pp. 17-26

2021

DOI: $10.53935 / 2641-533 x . v 4 i 1.62$

Corresponding Author: Subadrah Madhawa

Nair

Email: subadrah.nair@city.edu.my

Funding: This study received no specific

financial support.

Received: 3 September 2021

Revised: 29 September 2021

Accepted: 18 October 2021

Published: 1 November 2021

(C) 2021 by the authors; licensee Academic

Publishing Group Jankowski, 2017). According to Bjorklund (2012) females learn language more quickly than their male counterparts. In addition, Latham (2002) cites the report of Halpern in which he found out that females acquire some linguistic concepts earlier than male especially understanding the difference between active and passive voices. All these studies support the hypothesis that females and males acquire language differently and the general conclusion of these studies points out that females are more likely to perform better than males in second language acquisition.

According to Jule (2008) much research has been found to consolidate the claim that language is used distinctively by females and males, and there are different methods of investigating the relationship between male and female students' English achievement. The research of Yang and Huang (2018) studied the different 


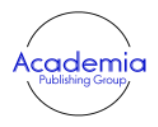

International Journal of Educational Studies

Volume 4, Issue 1, pp. 17-26

2021

DOI: $10.53935 / 2641-533 x . v 4 i 1.62$

- Corresponding Author: Subadrah Madhawa

Email:subadrah.nair@city.edu.my

Funding: This study received no specific

financial support.

Received: 3 September 2021

Revised: 29 September 2021

Accepted: 18 October 2021

Published: 1 November 2021

(C) 2021 by the authors; licensee Academic

Publishing Group

| 20 attitudes between males and females towards foreign language learning and the results were suggestive. Their findings indicated that females tend to learn languages more actively than males and they also highlighted that males show more tendency of disinclination to learn a foreign language than females. In regard to this, as far as second language acquisition is concerned, it is not only biological factors that influence second language acquisition of males and females, but also the attitudes of different genders do.

Bevilacqua (2017) indicated in his study that males and females possess different abilities in the use of memory, cognitive as well as compensation strategies. Montenegro and Jankowski (2017) also found that females outperform males in first and second language acquisition. Moreover, a study by Gray (2013) illustrated that female students perform much better than their male counterparts in a Japanese language class. Ginting (2018) also revealed that females obtain richer vocabulary than males and their lexical density in descriptive writing is significantly higher that that of males. Nevertheless, findings by Vaezi and Kafshgar (2012) indicated that between males and females, there was no significant difference in lexical complexity (diversity and density) in their essays.

Although gender differences have attracted considerable attention in EFL teaching and learning, there are few studies on the relationship between gender differences and the writing performance of EFL learners. As such, the current study mainly focused on the writing performance of EFL undergraduates according to gender and also attempts to explore the appropriate approaches to help students improve their writing skills.

\section{Methodology}

A descriptive research design is utilized in this study and both quantitative and qualitative researches are used. The study was conducted at Hunan City University which is situated in the northern part of Hunan Province of China. The population of the study is about 4,000 students and they are non-English major students, freshmen in Hunan City University, aged between 18 to 20 years old, enrolled in the academic year 2020. Purposive sampling is used to select 400 sample. The sample comprised of 200 male and 200 female first-year non-English major undergraduates from four faculties (Chinese Language, Information Technology, Civil Engineering and Education Management).

The descriptive writing test was used as an instrument to collect the quantitative data. The students were required to complete a descriptive writing task of 350 words within 90 minutes. Following that, students' essays were marked using the rubric provided by the researchers and the scores of each component of the essays were recorded.

The writing performances (quantitative data) of the 400 students' are analysed by Statistical Package for the Social Sciences for Windows (SPSS). Both Inferential Statistics (Independent Samples T-Test) and Descriptive Statistics (Mean and Standard Deviation) were used in the analysis.

Then, the qualitative data was collected. Face-to-face interviews are carried out with four EFL lecturers and the data was tape-recorded and transcribed. The qualitative data was analysed using emerging themes.

\section{Results and Discussion}

RQ1. Is there a significant difference in the overall mean score for descriptive writing among Chinese undergraduates students according to gender?

Table-1. Comparison of the overall mean score between male and female students in their descriptive writings.

\begin{tabular}{cccccccc}
\hline Group & $\mathbf{N}$ & Mean & Std. Deviation & Mean Difference & t-value & df & p-value \\
\hline Male & 200 & 62.94 & 5.844 & -3.635 & -5.538 & 398 & 0.000 \\
Female & 200 & 66.58 & 7.213 & & & & \\
\hline Note: Level of significance is at $\mathrm{p}<0.05$.
\end{tabular}

The findings in Table 1 demonstrate that the overall mean score of both the male and female students are not high which indicates that the average level of students' writing is not high. It also shows that the writing proficiency of the male students is lower (Mean=62.94, $\mathrm{SD}=5.844$ ) than their female counterparts (Mean=66.58, SD=7.213). Findings from the independent sample t-test shows that the performance of female students are significantly better than their male counterparts in their writings (Mean difference $=-3.635$, $t=-$ 5.538, $\mathrm{df}=398, \mathrm{p}=0.000$ ). Therefore, the findings have answered the Research Question 1. These findings are in line with the study of Hamdi and Dabaghi (2012) which holds that males and females perform significantly 
differently in second language acquisition. In addition, the study of Bevilacqua (2017) also indicates language function is more organized in females.

RQ2: Is there a significant difference in the mean score for introduction of descriptive writing according to gender?

Table-2. Comparison of the mean score for introduction between male and female students in their descriptive writings.

\begin{tabular}{cccccccc}
\hline Group & $\mathbf{N}$ & Mean & Std. Deviation & Mean Difference & t-value & df & p-value \\
\hline Male & 200 & 6.49 & 0.845 & -0.625 & -6.532 & 398 & 0.000 \\
Female & 200 & 7.12 & 1.057 & & & & \\
\hline
\end{tabular}

The results of Table 2 indicate that in the area of introduction part of the writing, male students' mean score is lower (Mean=6.49, $\mathrm{SD}=0.845$ ) than their female counterparts (Mean=7.12, $\mathrm{SD}=1.057$ ). Furthermore, the results of the independent sample t-test illustrates that the female students got higher scores than male students (Mean difference $=-0.625, \mathrm{t}=-6.532, \mathrm{df}=398, \mathrm{p}=0.000$ ). Therefore, Research Question 2 has been answered. These results support findings by Alhaisoni, Al-Zuoud, and Gaudel (2015) and Bevilacqua (2017) which stressed that females are more talented in learning languages.

RQ3: Is there a significant difference in the mean score for focus on topic of descriptive according to gender?

Table-3. Comparison of the mean score for focus on topic between male and female students in their descriptive writings.

\begin{tabular}{cccccccc}
\hline Group & N & Mean & Std. Deviation & Mean Difference & t-value & df & p-value \\
\hline Male & 200 & 13.67 & 1.319 & -0.510 & -3.407 & \multirow{2}{*}{398} & 0.001 \\
Female & 200 & 14.18 & 1.656 & & &
\end{tabular}

The findings in Table 3 show that the mean score for focus on topic of the male students is lower (Mean=13.67, SD=1.319) than their female counterparts (Mean=14.18, SD=1.656). The results of the independent sample t-test illustrate the female students significantly outperformed male students (Mean difference $=-0.510, \mathrm{t}=-3.407, \mathrm{df}=398, \mathrm{p}=0.001)$. Therefore, the findings have answered the Research Question 3. These results are consistent with findings by Chavez (2001); Akbar and Simin (2012) and Oxford (2015) which claimed that females obtain better learning strategies and learning styles than males so they do better in English writing.

RQ4: Is there a significant difference in the mean score for supporting details of descriptive writing according to gender?

Table-4. Comparison of the mean score for supporting details between male and female students in their descriptive writings.

\begin{tabular}{cccccccc}
\hline Group & $\mathbf{N}$ & Mean & Std. Deviation & Mean Difference & t-value & df & p-value \\
\hline Male & 200 & 8.97 & 1.065 & -0.545 & -4.555 & 398 & 0.000 \\
Female & 200 & 9.52 & 1.315 & & & & \\
\hline Note: Level of significance is at $\mathrm{p}<0.05$ & & & &
\end{tabular}

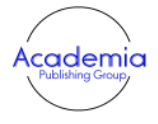

International Journal of Educational Studies

Volume 4, Issue 1, pp. 17-26

2021

DOI: $10.53935 / 2641-533 x . v 4 i 1.62$

"Corresponding Author: Subadrah Madhawa

Email: subadrah.nair@city.edu.my

Funding: This study received no specific

financial support.

Article History:

Received: 3 September 2021

Revised: 29 September 2021

Accepted: 18 October 2021

Published: 1 November 2021

(C) 2021 by the authors; licensee Academic

Publishing Group
According to the findings in Table 4, the mean score for supporting details of the male students is lower (Mean=8.97, SD=1.065) than the females (Mean=9.52, SD=1.315). Findings from the independent sample ttest indicate that there is significant difference in the mean score for supporting details between the male and female students in their writings (Mean difference $=-0.545, \mathrm{t}=-4.555, \mathrm{df}=398, \mathrm{p}=0.000$ ). The current findings show that female students perform significantly better than male students in supporting details in their descriptive writing. As such, the findings have answered the Research Question 4. These findings are parallel with the findings of Oxford (2015) and Chavez (2001) which pointed out that gender differences are associated with language learning effectiveness. Moreover, the findings also consistent with the research of Ginting (2018) which indicated that the females students have more lexical density than males in writing. RQ5: Is there a significant difference in the mean score for adding personal opinion of descriptive writing according to gender? 
Table-5. Comparison of the mean score for adding personal opinion between male and female students in their descriptive writings.

\begin{tabular}{cccccccc}
\hline Group & $\mathbf{N}$ & Mean & Std. Deviation & Mean Difference & t-value & df & p-value \\
\hline Male & 200 & 7.65 & 0.694 & -2.10 & -2.701 & 398 & 0.007 \\
Female & 200 & 7.86 & 0.853 & & & \\
\hline
\end{tabular}

Note: Level of significance is at $\mathrm{p}<0.05$

The results in Table 5 reveal that the mean score for adding personal opinion of the male students is lower (Mean=7.65, $\mathrm{SD}=0.694$ ) than the female students (Mean=7.86, $\mathrm{SD}=0.853$ ). Findings from the independent sample t-test show that there is significant difference in the mean score for adding personal opinion between the male and female students in their descriptive writings (Mean difference $=-2.10, \mathrm{t}=-2.701$, $\mathrm{df}=398$, $\mathrm{p}=0.007)$. Therefore, the findings have answered Research Question 5. These findings are consistent with findings by Bjorklund (2012); Akbar and Simin (2012) and Ginting (2018) who found that females learn language more quickly than their male counterparts.

RQ6: Is there a significant difference in the mean score for sentence structure of descriptive according to gender?

\begin{tabular}{|c|c|c|c|c|c|c|c|}
\hline Group & $\mathbf{N}$ & Mean & Std. Deviation & Mean Difference & t-value & df & p-value \\
\hline Male & 200 & 7.74 & 1.144 & \multirow{2}{*}{-0.480} & \multirow{2}{*}{-3.801} & \multirow{2}{*}{398} & \multirow{2}{*}{0.000} \\
\hline Female & 200 & 8.22 & 1.371 & & & & \\
\hline
\end{tabular}

The results in Table 6 show that the mean score for sentence structure of the male students is lower (Mean=7.74, $\mathrm{SD}=1.144$ ) than the female students (Mean=8.22, $\mathrm{SD}=1.371$ ). Findings from the independent sample t-test reveal that there is significant difference in the mean score for sentence structure between the male and female students in their descriptive writings (Mean difference $=-0.480, \mathrm{t}=-3.801, \mathrm{df}=398, \mathrm{p}=0.000$ ). As such, the finding have answered the Research Question 6. Therefore, these findings support the study by Gray (2013) and Montenegro and Jankowski (2017) which indicated that female's language progress is more rapid than that of males.

RQ7: Is there a significant difference in the mean score for coherence and cohesion of descriptive writing according to gender?

\begin{tabular}{cccccccc}
\multicolumn{6}{c}{ Table-7. Comparison of the mean score for coherence and cohesion between male and female students in their descriptive writings. } \\
\hline Group & N & Mean & Std. Deviation & Mean Difference & t-value & df & p-value \\
\hline Male & 200 & 6.08 & 0.792 & -0.525 & -5.779 & 398 & \multirow{2}{*}{0.000} \\
Female & 200 & 6.61 & 1.012 & & & & \\
\hline Note: Level of significance is at $p<0.05$ & & & & & &
\end{tabular}

It is illustrated in Table 7 that the mean score for coherence and cohesion of the male students is lower (Mean=6.08, SD=0.792) than the female students (Mean=6.61, SD=1.012). Findings from the independent sample t-test show that between the male and female students, there is significant difference in the mean score for coherence and cohesion in their descriptive writings (Mean difference $=-0.525, \mathrm{t}=-5.779, \mathrm{df}=398, \mathrm{p}=0.000$ ). In regard to this, the finding have answered the Research Question 7. These findings are parallel with findings by Akbar and Simin (2012) and Latham (2002) which indicated that females are better than males in their use of cognitive, memory and compensation strategies.

RQ8: Is there a significant difference in the mean score for conclusion of descriptive writing according to gender?

Table-8. Comparison of the mean score for conclusion between male and female students in their descriptive writings.

\begin{tabular}{cccccccc}
\hline Group & $\mathbf{N}$ & Mean & Std. Deviation & Mean Difference & t-value & df & p-value \\
\hline Male & 200 & 6.24 & 0.816 & -0.200 & -2.385 & \multirow{2}{*}{398} & \multirow{2}{*}{0.018} \\
Female & 200 & 6.44 & 0.860 & & \\
\hline
\end{tabular}

\footnotetext{
Internation

Volume 4, Issue 1, pp. 17-26

2021

DOI: $10.53935 / 2641-533 x . v 4 i 1.62$

Corresponding Author: Subadrah Madhawa

Nair

Email: subadrah.nair@city.edu.my

Funding: This study received no specific

financial support.

Article History:

Received: 3 September 2021

Revised: 29 September 2021

Accepted: 18 October 2021

Published: 1 November 2021

Publishing Group
} 
The findings from Table 8 indicate that the mean score for conclusion of the male students is lower (Mean=6.24, SD=0.816) than the female students (Mean=6.44, SD=0.860). Findings from the independent sample t-test show that there is significant difference in the mean score for conclusion between the male and female students in their descriptive writings (Mean difference $=-0.200, t=-2.385, \mathrm{df}=398, \mathrm{p}=0.018$ ). In regard to this, the finding have answered the Research Question 8. Therefore, these findings support the study by Gray (2013); Ginting (2018) and Akbar and Simin (2012) which showed that the females are indicated to do better than the males in their descriptive writing.

RQ9: Is there a significant difference in the mean score for grammar and mechanics of descriptive writing according to gender?

Table-9. Comparison of the mean score for grammar and mechanics between male and female students in their descriptive writings.

\begin{tabular}{cccccccc}
\hline Group & $\mathbf{N}$ & Mean & Std. Deviation & Mean Difference & t-value & df & p-value \\
\hline Male & 200 & 5.83 & 0.779 & -0.535 & -5.797 & \multirow{2}{*}{398} & \multirow{2}{*}{0.000} \\
Female & 200 & 6.36 & 1.047 & & &
\end{tabular}

The results in Table 9 indicate that the mean score for grammar and mechanics of the male students is lower (Mean=5.83, SD=0.779) than their female counterparts (Mean=6.36, $\mathrm{SD}=1.047$ ). Findings from the independent sample t-test show that there is significant difference in the mean score for grammar and mechanics between the male and female students in their descriptive writings (Mean difference $=-0.535$, $t=-$ 5.797, $\mathrm{df}=398, \mathrm{p}=0.000$ ). In regard to this, the finding have answered the Research Question 9. Therefore, these findings support the study by Latham (2002) which showed that the females are indicated to acquire linguistic concepts earlier and understand the grammar better than the males. However, the findings are opposite with the research of Vaezi and Kafshgar (2012) which indicated that in descriptive writing, male and female students have no significant difference on lexical complexity (diversity and density).

RQ10: What are the EFL lecturers' perceptions on how to help students improve their writing skills?

The researcher conducted a semi-structured interview with four EFL lecturers of the students who participated in the study. The lecturers expressed their opinions on how to help the students improve their writing skills. In this part, the lecturers' answers to the questions are presented with Emerging Themes.

The following are qualitative data results based on lecturers' responses to four interview questions:

1. What types of errors do your students make in their descriptive writing?

2. Why do you think they make these kinds of errors?

3. Between male and female students, who do you think make more errors in descriptive writing? Please explain.

4. What should you do to improve your students' English writing ability? Please explain.

1. What types of errors do your students make in their descriptive writing?

Table-10. Emerging themes from lecturers' responses to Interview Question 1

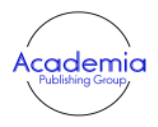

International Journal of Educational Studies

Volume 4, Issue 1, pp. 17-26

2021

DOI: $10.53935 / 2641-533 x . v 4 i 1.62$

"Corresponding Author: Subadrah Madhawa

Nair

Email: subadrah.nair@city.edu.my

Funding: This study received no specific

Funding: This study

Article History:

Received: 3 September 2021

Revised: 29 September 2021

Accepted: 18 October 2021

Published: 1 November 2021

(C) 2021 by the authors; licensee Academic Publishing Group
Lots of errors, many types of errors.
Grammatical errors: misuse of part of

Grammatical errors: misuse of part of speech, inconsistency between subject and predicate, inconsistency of personal pronoun, confusion of tense, wrong passive sentence, make improvement through lecturers' feedback.

Mechanical errors: capitalization and punctuation, fewer compared with other types of errors.

Lexical errors: incorrect word choice, wrong use of auxiliaries, wrong use of articles.

Coherence and cohesion errors: confused with logic, word-order errors, wrong or poor use of cohesive and cohesion words.

sentence structure errors: the omission of item, the addition of items,

Large quantities of Chinglish.

The emerging themes in Table 10 pointed out that there are a lot of errors in their students' writings: they are grammatical errors, mechanical errors, lexical errors, coherence and cohesion errors and structural errors. Moreover, they revealed that there were Chinglish style of writing in their students' essays. In addition, they also stressed that her students were weak in word choice and they often use simple words or phrases to express their ideas. They also mentioned that the students often use wrong articles. Moreover, the lecturers 
also referred that the number of students' writing errors were reduced after they received the lecturers' feedback.

2. Why do you think they make these kinds of errors?

Table-11. Emerging themes from lecturers' responses to Interview Question 2.

no enough practice, weak foundation, small vocabulary, low competence in English writing, limited knowledge about English, the influence of native language (Chinese)

poor grammar: differences between Chinese grammar and English grammar, thinking in Chinese instead of English while writing, hate grammar, shut off minds and stare at lecturers blankly in class, different spelling between Chinese and English, tendency to use Chinese sentence structure, lack afterclass training, have no confidence, lack of interest, carelessness, no habit of revising the drafts.

The emerging themes in Table 11 illustrated that as the grammar of English is totally different from Chinese language, the students are weak in English writing. Moreover, their English foundation is weak and they do not have enough practice in English writing. They also indicated that the students get used to thinking in Chinese instead of English while writing, which is of no benefit to enhance their English. The lack of interest in English and bad study habit are also the obstacles in in improving their English.

3. Between male and female students, who do you think make more errors in descriptive writing? Please explain.

Table-12. Emerging Themes from lecturers' responses to Interview Question 3.

Male students: make more errors than female students, do not take writing task seriously, show less interest in English, generally careless, have a strong spirit of adventure to write the so-called high score sentence patterns, poor grasp of knowledge

Female students: learn more seriously and carefully than male students

Reasons: different brain functions, different study habits, different ability in utilizing learning strategies, the motivations.

According to the lecturers' responses in Table 12, male students make more errors than female students because some males do not take the writing task seriously and they are generally more careless than females. They also indicated that male students have a strong spirit of adventure to write the so-called high score sentences which is a vital cause of making errors. As for females, the lecturers showed that, they generally obtain better learning habits than males and also have stronger motivations in foreign language learning. Moreover, female students were discovered to be more willing to interact with others and use more strategies while learning.

4. What should you do to improve your students' English writing ability? Please explain.

Table-13. Emerging Themes from s' responses to Interview Question 4

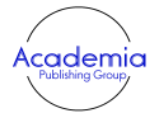

International Journal of Educational Studies

Volume 4, Issue 1, pp. 17-26

2021

DOI: $10.53935 / 2641-533 x . v 4 i 1.62$

Corresponding Author: Subadrah Madhawa

Email: subadrah.nair@city.edu.my

Funding: This study received no specific

financial support.

Article History:

Received: 3 September 2021

Revised: 29 September 2021

Accepted: 18 October 2021

Published: 1 November 2021

(C) 2021 by the authors; licensee Academic Publishing Group
Keep enriching vocabulary, enhance the ability to analyse long and difficult sentences, ask students to read more and write more, help them master the basic sentence structure and strengthen the training to help them improve in writing, correct sentences in accordance with the grammatical rules, practise and ameliorate the process approach in class, train students' ability of thinking logically and critically before writing, help them master the writing skills in various genres of writing, carry out targeted teaching (build up different teaching aims for students with different writing proficiency)

The lecturers' responses in Table 13 indicated that it is necessary to strengthen students' English foundation to improve their writing level, which is mainly reflected in enriching their vocabulary and improving the understanding and analyzing ability of sentence structure. They also emphasized that more practice in reading and writing is quite useful. Moreover, the lecturers proposed to use process approach to teach writing and it is important to teach students writing skills about all the genres of writing.

\section{Conclusion}

The study investigated Chinese undergraduate students' descriptive writing skills according to gender and lecturers' views on how to enhance their students' writing ability. The results of the quantitative data showed 
that female students perform significantly better than male students in the overall mean score as well as in Introduction, Focus on Topic, Supporting Details, Adding Personal Opinion, Sentence Structure, Coherence and Cohesion, Conclusion and Grammar and Mechanics.

In addition, the qualitative data are consistent with the findings of the quantitative data, which indicate that female students perform significantly better in descriptive writing. The face-to-face interview with the EFL lecturers indicated that they took several approaches to enhance their students' writing proficiency. They also stressed that the Process Approach is very useful in helping students build a solid foundation in English writing.

There are theoretical implications in this study. The findings indicated that EFL lecturers could utilize Process Approach in writing class and they should make full use of the writing rubric: First, the lecturer should make students fully understand the standard of a good composition; Second, the lecturer should fully combine the rubric in the Process Approach and highlight the key points to achieve the learning outcomes.

Pedagogically, the findings recommend that it is necessary for EFL lecturers to take appropriate teaching strategies to enhance male students' writing skills. Based on these results, the lecturers should also employ effective writing strategies to motivate the male students in English writing.

Moreover, limitations are also needed to be noted in the study. First and foremost, the sample size of this study only consists of 400 undergraduates from one Chinese university. Therefore, it is suggested that studies in the future will involve a more extensive sample from different universities in other provinces of China. In addition, it is hoped that future researchers could do quasi-experimental studies on how to minimize students' errors in writing and improve their writing skills through utilizing the process approach effectively.

\section{References}

Akbar, A., \& Simin, Z. (2012). Exploring the gender effect on EFL learners' learning strategies. Theory and Practice in Language Studies, 2(8), 1614-1620. Available at: https://doi.org/10.4304/tpls.2.8.16141620.

Akyol, H., Çakıroğlu, A., \& Kuruyer, H. G. (2014). A study on the development of reading skills of the students having difficulty in reading: Enrichment reading program. International Electronic Journal of Elementary Education, 6(2), 199-212.

Alhaisoni, E. M., Al-Zuoud, K. M., \& Gaudel, D. R. (2015). Analysis of spelling errors of Saudi beginner learners of english enrolled in an intensive English language program. English Language Teaching, 8(3), 185-192. Available at: https://doi.org/10.5539/elt.v8n3p185.

Andrade, H. G. (2005). Teaching with rubrics: The good, the bad, and the ugly. College Teaching, 53(1), 27-31. Available at: https://doi.org/10.3200/ctch.53.1.27-31.

Badger, R., \& White, G. (2000). A process genre approach to teaching writing. ELT Journal, 54(2), 153-160.

Bevilacqua, A. (2017). Commentary: Should gender differences be included in the evolutionary upgrade to cognitive load theory? Educational Psychology Review, 29(1), 189-194. Available at: https://doi.org/10.1007/s10648-016-9362-6.

Bjorklund, D. F. (2012). Children's thinking: Cognitive development and individual differences. Australia, Belmont, CA: Thomson/Wadsworth

Cargill, K., \& Kalikoff, B. (2007). Linked psychology and writing courses across the curriculum. The Journal of General Education, 56(2), 83-92. Available at: https://doi.org/10.1353/jge.2007.0017.

Chavez, M. (2001). Gender in the language classroom. Boston: McGraw Hill.

Cole, J. (2015). Effective strategies for improving writing skills of elementary English language learners. Mount Royal Undergradute Education Review, 1(3), 1-11.

Corona, R., Rodríguez, V. M., McDonald, S. E., Velazquez, E., Rodríguez, A., \& Fuentes, V. E. (2017). Associations between cultural stressors, cultural values, and Latina/o college students' mental health. Journal of Youth and Adolescence, 46(1), 63-77. Available at: https://doi.org/10.1007/s10964-016-0600-5.

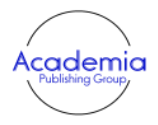

International Journal of Educational Studies

Volume 4, Issue 1, pp. 17-26

2021

DOI: $10.53935 / 2641-533 x . v 4 i 1.62$

- Corresponding Author: Subadrah Madhawa

Nair

Email: subadrah.nair@city.edu.my

Funding: This study received no specific

financial support.

Received: 3 September 2021

Revised: 29 September 2021

Accepted: 18 October 2021

Published: 1 November 2021

(C) 2021 by the authors; licensee Academic

Publishing Group

25

Cumming, A. (2003). Experienced ESL/EFL writing instructors' conceptualizations of their teaching: curriculum options and implications. In B. Kroll (Ed.), Exploring the Dynamics of Second Language Writing (pp. 71-92). New York: Cambridge University Press.

Divsar, H., \& Heydari, R. (2017). A corpus-based study of EFL learners' errors in IELTS essay writing. International Journal of Applied Linguistics and English Literature, 6(3), 143-149. Available at: https://doi.org/10.7575/aiac.ijalel.v.6n.3p.143.

Freud, S. (1974). The standard edition of the complete works of sigmund freud (pp. 241-258). London: The Hogart Press.

Ginting, S. A. (2018). Syntactic Complexity on Extroverted and Introverted Indonesian Language Learners' Written Products. International Journal of Education and Literacy Studies, 6(4), 101-106. Available at: https://doi.org/10.7575/aiac.ijels.v.6n.4p.101.

Graham, S., \& Harris, K. R. (2005). Writing better: Effective strategies for teaching students with learning difficulties. Baltimore: Brooks.

Gray, S. S. (2013). Framing "at risk" students: Struggles at the boundaries of access to higher education. Children and Youth Services Review, 35(8), 1245-1251. Available at: https://doi.org/10.1016/j.childyouth.2013.04.011.

Hamdi, A. S., \& Dabaghi, A. (2012). Gender differences in Iranian EFL students' letter writing. International Journal of Applied Linguistics \& English Literature, 1(7), 155- 169. Available at: https://doi.org/10.7575/ijalel.v.1n.7p.155. 
Hasan, M. K., \& Akhand, M. M. (2010). Approaches to writing in EFL/ESL context: Balancing product and process in writing class at tertiary level. Journal of NELTA, 15(1-2), 77-88. Available at: https://doi.org/10.3126/nelta.v15i1-2.4612.

Ibrahim, M. A. (2015). University students' English writing problems: Diagnosis and remedy. International Journal of English Language Teaching, 3(3), 40-52.

Jule, A. (2008). A beginner's guide to language and gender. Clevedon, Eng. Buffalo, NY: Multilingual Matters.

Latham, D. (2002). How children learn to write: Supporting and developing children's writing in schools. London: Paul Chapman.

Li, Z., Chen, M. Y., \& Banerjee, J. (2020). Using corpus analyses to help address the DIF interpretation: Gender differences in standardized writing assessment. Frontiers in Psychology, 11, 1088. Available at: https://doi.org/10.3389/fpsyg.2020.01088.

Liu, Y. T. (2015). Foreign language education planning in China since 1949: A foreign language education planning in China since 1949: A recurrent instrumentalist discourse. Working Papers in Educational Linguistics, 30(1), 65-85.

Montenegro, E., \& Jankowski, N. A. (2017). Equity and assessment: Moving towards culturally responsive assessment. Urbana, IL: University of Illinois and Indiana University, National Institute for Learning Outcomes Assessment (NILOA).

Oxford, R. (1994). La difference: Gender differences in second/foreign langauge learning styles and strategies. In: J. Sunderland (Ed.), Exploring Gender: Questions and Implications for English Language Education (pp. 140-147). New York: Prentice Hall.

Oxford, R. (2015). A language is a mentality: A narrative, positive-psychological view of six learners' development of bilingualism. Manoa: Second Language Teaching \& Curriculum Center, University of Hawaii at Manoa.

Ronald, T. K., \& Bascom, A. R. (2007). Improving the writing skills of college students. Psychonomic Bulletin \& Review, 14(2), 237242.

Sang, Y. (2017). Investigate the "issues" in Chinese students' English writing and their "reasons": revisiting the recent evidence in Chinese academia. International Journal of Higher Education, 6(3), 1-11. Available at: https://doi.org/10.5430/ijhe.v6n3p1.

Tangpermpoon, T. (2008). Integrated approaches to improve students writing skills for English major students. ABAC Journal, 28(2), $1-9$.

Tavsanli, O. F., \& Kaldırım, A. (2020). Process based writing approach in Turkey: A thematic analysis study. Cumhuriyet International Journal of Education, 9(1), 108-138.

Tompkins, G. E. (2002). Language arts. Content and teaching strategies. New Jersey: Prentice- Hall.

Vaezi, S., \& Kafshgar, N. B. (2012). Learner characteristics and syntactic and lexical complexity of written products. International Journal of Linguistics, 4(3), 671-687. Available at: https://doi.org/10.5296/ijl.v4i3.2391.

Voyer, D., \& Voyer, S. D. (2014). Gender differences in scholastic achievement: A meta-analysis. Psychological Bulletin, 140(4), 1174-1204. Available at: https://doi.org/10.1037/a0036620.

Yang, L.-C., \& Huang, S.-H. (2018). A closer look at language learning motivational strategies (LLMS): learners' preference and the role of gender. Journal of Higher Medical General Education, 13(1), 77-108.

Zhang, Y. (2021). Approaches to English writing instruction based on corpus technology. Journal of Advances in Education and Philosophy, 5(8), 270-274.

\author{
International Journal of Educational \\ Studies \\ Volume 4, Issue 1, pp. 17-26 \\ 2021 \\ DOI: $10.53935 / 2641-533 x . v 4 i 1.62$ \\ Corresponding Author: Subadrah Madhawa \\ Nair \\ Email:subadrah.nair@city.edu.my \\ Funding: This study received no specific \\ financial support. \\ Received: 3 September 2021 \\ Revised: 29 September 202 \\ Accepted: 18 October 2021 \\ Published: 1 November 202 \\ (C) 2021 by the authors; licensee Academic \\ Publishing Group
}

| 26 